\title{
Surface Treatment of Magnesium Alloys by Electroless Ni -P Plating Technique with Emphasis on Zinc Pre-treatment: a Review
}

\author{
Nahed El Mahallawy \\ Engineering and Material Science Department, The German University in Cairo, Egypt, \\ Nahed.elmahallawy@guc.edu.eg
}

\begin{abstract}
Keywords: Magnesium alloys; surface treatment; electroless Ni-P plating; pre-treatment; coat morphology; EDX analysis; hardness; corrosion behaviour
\end{abstract}

\begin{abstract}
Magnesium alloys are attractive alloys in industrial applications, where light weight and good strength structures are required. Magnesium alloys are versatile and include both cast and wrought alloys. However, they have a drawback as they are prone to corrosion especially in harsh environments. For this reason, surface treatment of magnesium alloys is of prime importance for improving their corrosion characteristics.

In the present paper, a survey of the different methods for surface treatment of magnesium alloys is presented and discussed. This is followed by a review of the recent work on electroless Ni plating technique with zinc pre-treatment applied on several magnesium alloys and the effect of pretreatment and post heat treatment on the coat characteristics. The surface morphology, surface roughness, thickness of the layer, EDX analysis, adhesion, hardness and corrosion resistance are covered in this review.
\end{abstract}

\section{Introduction}

Magnesium alloys are the lightest alloys used as structural metals with about $2 / 3$ the density of aluminium. They are attractive for several industrial applications, where light weight and good strength structures are required due to their high specific strength and modulus and excellent antischock resistance. The heat conductivity and electromagnetic shielding effectiveness are also added to the advantages of magnesium alloys for IT and for communication industries [1-3]. However, they have a drawback as they are prone to atmospheric corrosion. Because of their high chemical affinity to aquaous solutions, it is a difficult metal for electrochemical treatments.

Several methods have been applied in order to improve the corrosion characteristics of cast and wrought magnesium alloys. These methods will be summarized then the electroless technique will be presented in details.

\section{Different Surface Treatments of Magnesium Alloys}

Different techniques of surface treatment for magnesium and its alloys are found in the literature for improving corrosion and wear resistance. Coatings can be either for a decorative purpose or a functional purpose, like corrosion and wear resistance, hardness, emission and reflection of light or heat, conductivity, solderability.

In case of magnesium alloys, the presence of alloying elements introduce an electrochemical heterogeneity which makes the situation even more complex, in addition to the poor corrosion resistance of magnesium [3]. Furthermore, it was found that the increase of surface roughness affects negatively the corrosion resistance [4], which is also affected by modification of microstructure through heat treatment [5].

Coating is among the most commonly used surface treatments for magnesium including chemical inorganic, inorganic conversion coating and anodizing ( e.g. chromating, fluorzirconate treatment), organic , metallic, ceramic coating, as well as composite coatings. 
Inorganic protective layers are a necessary precondition for the application of organic coatings afterwards. The conversion or anodizing layer is necessary for satisfactory corrosion resistance. A comparison between chromating and hard anodizing is presented in [5]. Chemical conversion coating and anodizing with chromate solutions, although proven effective in protecting the magnesium alloys from corrosion, could cause serious environmental problems. For this reason, several publications deal with non chromate conversion coating [6-13]. A chromate-free phosphate-permanganate bath showed promise as a paint-base treatment for magnesium alloy die castings [8].

Other techniques for improving corrosion resistance of magnesium alloys have been applied including sputter deposition [14], vapour deposition [15], application of oxide coating[16 ], sol gel coating [17], thermal spray of different alloys on magnesium surfaces [18] and coating with high purity magnesium due to its relatively higher corrosion resistance [19].

Surface alloying was achieved by several methods including diffusion, electron beam and laser alloying. An aluminium diffusion coating was made on AZ91 alloy by heat treatment of the magnesium alloy for $1 \mathrm{~h}$ at $450^{\circ} \mathrm{C}$ in $\mathrm{Al}$ powder under argon atmosphere, resulting in a 780 micron layer of intermetallic Al-Mg. The surface hardness increased by this treatment from $60 \mathrm{HV}$ to $160-$ $170 \mathrm{HV}[20,21]$. A similar alloying with aluminium was achieved on AZ91 and ZC63 using electron beam [22]. The additional aluminium was first deposited onto a substrate then the deposit was remelted by an electron beam. As the material resolidified at a high cooling rate, intermetallic phases were formed which improved the wear resistance. Laser alloying was also applied successfully but was not found suitable for large surfaces due to shrinkage cracking [23]. Laser clads for cylinder liners were produced on magnesium base alloys using $10 \mathrm{~kW} \mathrm{CO}$ laser and powder mixtures composed of $\mathrm{Al}+\mathrm{Cu}, \mathrm{Al}+\mathrm{Si}$ and an alloyed $\mathrm{Al}$-Si powder in the single step. Intermetallic phases were obtained and an acceptable corrosion resistance was achieved [24]. In general, the formation of intermetallic phases may not be attractive for some applications where bending or schocks during service are expected. This is due to the poor ductility of the intermetallic phases formed in the coat.

Building hard ceramic-type layers on the surface was also achieved using several techniques, like plasma electrolytic oxidation, Magoxide, Tagnite and keronite [25-27]. Silicon oxide layer - Tagnite process - as a conversion layer for further painting on magnesium alloys was developed by an electrochemical process [28] and a new anodic coating using Magnoxid-coat applied on die cast alloys[29-30] was found to improve the corrosion resistance of AZ31 alloy [5]. However, Sharma [3] reported that the non-chromate conversion coating and anodizing cannot produce a reliable and effective result.

A new generation of Keronite process was found to produce hard, smooth and compact layers on $\mathrm{Mg}$ in addition to being environmental friendly. It is a bath-based treatment, where pulsed voltage is applied to the substrate and the resulting spark creates a fused ceramic layer on the surface. The treatment was followed by sealing of the coat to reduce porosity and increase corrosion resistance [31]. In another work [32-33], the coat was created by an electrolytic plasma reaction or a micro arc oxidation which permits functional coatings on a detailed surface resulting in satisfactory surface roughness, good adherence, good corrosion resistance and a surface hardness of 500-600 HV. The coating base was $\mathrm{MgO}, \mathrm{MgAl}_{2} \mathrm{O}_{4}, \mathrm{MgSiO}_{3}$, the quantitative relation between which was defined by both the electrolyte structure and the electrolysis parameters.

Combined coating composed of a ceramic hard coat and a functional polymer for providing dry lubrication ability was found to present an economical solution on small end components [34].

An approach consisting of modification of the $\mathrm{Mg}$ alloy by small $\mathrm{Ca}$ additions $-0.5 \%$ - was found to improve the corrosion resistance of AS41- $\mathrm{Mg}$ alloy [35]. This was achieved through stabilization of the formed corrosion product film by incorporating the relatively large $\mathrm{Ca}$ ions. The effect of the $\mathrm{Ca}$ content on the corrosion rate was found to depend strongly on the extent to which $\mathrm{Ca}$ is dissolved in the $\mathrm{Mg}$. In most cases, the coating was not completely satisfactory or needed several steps to reach satisfaction. Modification of the $\mathrm{Mg}$ alloy by small additions of alloying elements, such as $\mathrm{Ca}, \mathrm{Mn}$ or rare earth $(\mathrm{Gd}, \mathrm{Ce}, \mathrm{Nd}, \mathrm{Y})$ or even surface modification with hydrogen, 
was found to improve the corrosion resistance of $\mathrm{Mg}$ alloys [8,9,10 and 36]. Although the addition of several alloying elements such as aluminium, zinc and rare earths have been reported to improve the corrosion resistance [8,38], however, this does not satisfy the technological requirements for several applications as reported by R. Ambat et al [39].

The use of organic electrolyte for electroplating of magnesium with aluminium was developed by Siemens for industrial applications [40], however, the process is still expensive for large size products. Recently, low cost ionic liquids were successfully used for electrodeposition of zinc onto several Mg alloys -aluminium-free [41]. The ionic mixture was a non - aquaous electrolyte mixture composed of choline chloride and urea, stable in air and water, thus electrodeposition was possible in air at ambiant temperatures. Pulsed current was found suitable for the deposition. The corrosion behaviour of the coated $\mathrm{Mg}$ was found to be similar to that of zinc in a solution containing $\mathrm{NaCl}$. This process has the advantage of the low cost of the ionic liquid mixture used and the possibility of treating large areas. Further development of the technique is still needed in order to cover different types of Mg alloys.

The application of metallic coatings on magnesium surfaces was found to provide a corrosion resistance in addition to a conductive, high temperature resistant, hard, reflective, and solderable surface. Al12Si alloy was deposited by plasma spraying on Mg AS41/carbon short fibre composite, then remelted using $\mathrm{CO}_{2}$-laser beam (laser clad) [42], but the process parameters had to be very restricted in order to prevent the temperature rise of the $\mathrm{Mg}$ surface, as well as the porosity formation after laser remelting .

The application of aluminium coating on AZ31 alloy was achieved by arc spray coating followed by a post treatment consisting of hot pressing to reduce the amount of pores present in the coating layer, then a final anodizing treatment was applied. This treatment improved remarkably the corrosion resistance of the alloy in $\mathrm{NaCl}$ solution, but the process is depending on the geometry of the component for the step of pressure application [43]. Recently, PVD technique was applied to deposit Al on AZ31 Mg alloy [44]. Successful coating was obtained using preheating of the substrate followed by ion etching prior to coat deposition, all taking place in argon atmosphere. Good corrosion resistance was obtained when an intermedite phase was formed between the $\mathrm{Al}$ and the $\mathrm{Mg}$. The process seems promising especially for large surface areas as in case of sheets and strips, however, more work is still needed in order to improve the adherence at the interface between the coat and the $\mathrm{Mg}$ substrate.

Thermal spray of AlSi5 using arc spray coating was investigated with a pre and post- heat treatment [9], but the coat was found to include very high porosity, thus sealing with epoxy or polyurethane was necessary. Another technique using high velocity oxy-fuel (HVOF) sprayed $\mathrm{NiCr}$ and $\mathrm{NiCr}-\mathrm{Cr}_{3} \mathrm{C}_{2}$ coat was found to have good adherence to the substrate, however, the presence of microporosity caused severe corrosion at the interface between the coat and substrate [9].

Direct electroplating of magnesium is difficult due to the high reactivity of the substrate with aqueous solutions. However pulsed plating of $\mathrm{Zn}-\mathrm{Ni}$ alloy was successfully achieved on AZ91 Mg alloy [45]. The process includes polishing- chemical cleaning- acid pickling-activation- zinc immersion- zinc-copper plating and zinc-nickel plating. The zinc immersion step was mainly to improve the adhesion between the outer layers and the substrate while the $\mathrm{Zn}-\mathrm{Cu}$ layer was to reduce the electrode potential difference between the $\mathrm{Zn}-\mathrm{Ni}$ layer and the substrate for better protection against corrosion. It is to be noted that the $\mathrm{Zn}-\mathrm{Ni}$ coat was obtained by pulsed electrodeposition, where the pulse parameters had a great effect on the chemical composition, thickness, and microstructure of the coat. The results indicate that the parameters have to be accurately selected in order to reach good adherence and corrosion resistance.

It is clear from these surface treatments of $\mathrm{Mg}$ alloys that the processes are complex and need several steps, in addition to an accurate surface preparation and procedure. Every process has its advantages and limitations. Some can effectively be applied to only small areas or simple shapes, while others may destroy the heat treatment of the substrate due to application of heat.

Electroless $\mathrm{Ni}-\mathrm{P}$ coats are being increasingly used as a protective layer against wear and corrosion of conductive and non conductive materials, and a uniform coat is formed on the product 
surface with no restriction on the shape [46-49]. The process will be presented and the results reviewed in the next paragraphs regarding its application to magnesium alloys.

\section{Electroless Plating}

Electroless plating involves the deposition of coatings from solutions of metallic salts and reducing agents through the application of moderate heat. The process is generally described as a controlled autocatalytic chemical reduction process for depositing the desired alloy and is simply achieved by dipping the substrate into an electroless bath under appropriate plating conditions. Electroless deposition progresses with time, similar to electroplating, and quite heavy deposits can be produced [46-48]. It can be applied to conductive and non conductivre surfaces and to complex products uniformly.

Electroless deposits consist mainly of Ni, Ni-P and other ternary Ni alloys as well as copper. The process also offers the possibility to deposit composite coatings [46]. Electroless Ni-P coats are being increasingly used as a protective layer against wear and corrosion. They provide, in general, a high degree of corrosion resistance at elevated temperatures as well as good brazability, and solderability due to good wettability to the soldering material [3].

The nickel coat is of special importance in electronic industry due to its electrical conductivity and magnetic properties [46-49]. Electroless Ni-P coatings are favourable over electroplated deposits because of the uniformity of the coating on complex shaped objects. The deposit has less porosity and higher hardness $(480 \mathrm{HV})$ than electro deposited metal $(200 \mathrm{HV})$ because phosphorous is incorporated in the structure [46-48]. With further heat treatment at $400^{\circ} \mathrm{C}$ for $1 \mathrm{~h}$, the hardness of the deposit further increases resulting in a higher wear resistance. The process has a good throwing power in addition to low labour cost. However, expensive solutions, and careful analytical control of the bath are needed [3]. The process has been further developed by the application of multi-layer Ni-P with higher P content on the surface or the use of multi layer sol-gel and DC electroplating in order to improve the corrosion resistance in severe environments [ 20, 50, 51].

\section{Pre-treatment Processes prior to Electroless Ni ( EN) Plating of Magnesium Alloys}

Magnesium and its alloys are classified as hard-to-plate metals due to their high reactivity. The most difficult part of plating $\mathrm{Mg}$ is developing an appropriate pre-treatment process. The oxide layer which is rapidly formed on the magnesium surface prevents further successful plating and good adhesion of the coat to the substrate. For this reason pre-treatment of the surface is necessary in order to introduce a surface layer that prevents oxidation, provides adherence to the substrate and allows Ni plating to be uniform and defect -free. Pre-treatment processes of $\mathrm{Mg}$ alloys are mainly classified as zinc immersion and direct electroless plating by Gray and Luan [9]. These processes require many steps, are time consuming and must be precisely controlled to give acceptable adherence and corrosion resistance [9]. More recently, several pre-treatment processes are proposed in order to improve the adherence and Ni-P electroless coat quality. They can be classified as:

1. Treatment prior to direct electroless plating

2. Chemical conversion treatment, and

3. Zinc immersion,

The first two pre-treatments for Ni plating will be shortly presented while zinc immersion will be presented in details. 
1. Treatment prior to direct electroless plating

In the critical review of Gray and Luan [9], direct electroless Ni plating was a pre-treatment by itself. In recent developments, a pre-treatment was first applied before the direct electroless $\mathrm{Ni}$ plating to obtain the top coat.

A pre-treatment in an acid pickle solution containing $\left(\mathrm{CrO}_{3}+\mathrm{HNO}_{3}\right)$ prior to direct electroless Ni-P plating was undertaken on AZ91D $\mathrm{Mg}$ alloy using a plating bath containing sulphate nickel and HF [52]. The effect of treatment time up to $60 \mathrm{sec}$ was studied. The results indicated that with prolonging the treatment time, the electroless Ni-P deposits became more compact and defect free and that the deposition rate was proportional to this time, reaching 25 $\mu \mathrm{m} / \mathrm{hr}$ for $60 \mathrm{sec}$ acid pickling.

In most treatments, hexavalent chromium compounds and hydrogen fluoride acid during pre-treatment were used which are harmful to the environment [53]. The recent trend is towards finding environmental and health friendly technologies that can effectively inhibit the corrosion of $\mathrm{Mg}$. In this respect, an environmental friendly plating bath for direct electroless Ni plating was developed [ 54]. However, the pre-treatment included pickling in chromic acid and activation in HF solution. The plating bath contained nickel sulphate alkaline solution as the main salt. In the nonfluoride plating solution, $\mathrm{Na}_{2} \mathrm{CO}_{3}$ as a buffer agent, was found useful in increasing the growth rate of the plating coating, adjusting the adhesion between the coat and substrate and maintaining the $\mathrm{pH}$ value in the range from $8.5-11$ which was successful when $\mathrm{NiSO}_{4} \cdot 6 \mathrm{H}_{2} \mathrm{O}$ was used as the main salt. Trisodium citrate dehydrate with a concentration of $30 \mathrm{~g} / \mathrm{l}$ was found to be an essential component in the plating bath. The coat was crystalline, with low porosity, high density, and good corrosion resistance.

Improving the quality of direct electroless Ni-P deposit was achieved by applying mechanical attrition ( MA) during electroless Ni plating [55]. It reduced the pores and cracks in the deposit. The plating was applied after HF activation and was achieved by strirring the plating solution in which small alumina balls were introduced. The bath main salt was nickel carbonate, $\mathrm{pH}$ 6.5 for $60 \mathrm{~min}$. The deposit obtained was $\mathrm{Ni}$ and $\mathrm{Ni}_{3} \mathrm{P}$ phases fully crystallized with a hardness of $434 \mathrm{VHN}$ after MA.

As a pre-treatment, it was found that formation of $\mathrm{Mg}$ fluoride film over the substrate prevents oxidation of $\mathrm{Mg}$ during transfer to the plating bath where the Ni deposition takes place by replacement of the fluoride film [39]. Therefore, in an optimized bath, fluoride should be an essential component.

\section{Chemical conversion treatment}

Conversion coatings are produced by chemical or electrochemical treatment of a metal surface to produce a layer of oxides, chromates, phosphates or other compounds that are chemically bonded to the surface [9]. They are used as pre-treatment for $\mathrm{Mg}$ to provide corrosion resistance and good paint-base to the metal, acting as an insulating barrier between the metal and the surrounding environment. Chromate, phosphate permanganate, fluorozirconate, stannate treatments are summarised in ref. 9.

One of the main problems with conversion coatings is the toxicity of their solutions which contain chromium oxide or chromates. Recently, environmental friendly solutions have been proposed and the process is used as a pre-treatment prior to electroless Ni plating on $\mathrm{Mg}$ alloys.

A chromium-free solution was proposed as pre-treatment on AZ91D alloy to replace the solution containing hexavalent chromium and HF [56]. A phosphate-manganese conversion film was developed as a pre-treatment layer. The layer reduced the corrosion current density of the substrate and decreased the potential difference between matrix and second phase. The process steps included grinding, alkaline cleaning, rinsing, immersion in pre-treatment bath for $2 \mathrm{~min}$ where $\mathrm{H}_{3} \mathrm{PO}_{4}$ and $\mathrm{Mn}\left(\mathrm{H}_{2} \mathrm{PO}_{4}\right)_{2}$ were the main ingredients, rinsing, then electroless Ni-P plating with $\mathrm{NiSO}_{4} \cdot 6 \mathrm{H}_{2} \mathrm{O}$ as the main salt. The subsequent Ni-P layer became more compact, defect free and exhibited good anti-corrosion properties compared with the traditional pre-treatment. 
A conversion treatment in an alkaline stannate solution was applied on AZ91D surface prior to the Ni-P electroless coat [57]. The process steps include sensitization, activation, reduction then $\mathrm{Ni}-\mathrm{P}$ deposition. The procedure reduced the potential difference between the coat and substrate and enhanced the corrosion resistance. A porous structure of the chemical conversion coat formed on the $\mathrm{Mg}$ surface, provided an advantage for the adsorption during sensitization treatment with $\mathrm{SnCl}_{2}$ before electroless Ni plating.

\section{Intermediate layers and zinc immersion}

In general, the introduction of an intermediate layer (or interlayer) between the $\mathrm{Mg}$ substrate and the electroless $\mathrm{Ni}$ coat has the advantage of isolating the substrate from the Ni-P film, therefore improving the corrosion resistance [53]. The intermediate layers that will be presented in the following, include mainly an organic layer, a zinc phosphate layer, a copper layer and a zinc transition layer, which are all followed by electroless Ni plating.

The organic intermediate layer presented in [53] was an organosilicon heat resisting varnish. The process included precleaning, coating interlayer, surface roughing, surface activation using Pd colloid activator, dissolving Pd colloid, then electroless Ni plating. The time was 30 minutes for organic coating, followed by 1 hour drying at $180{ }^{\circ} \mathrm{C}$, then roughing for $30 \mathrm{~min}$ in $\mathrm{NaOH}$ solution, then surface activation for $10 \mathrm{~min}$, dissolving colloid for $1 \mathrm{~min}$, then coating in nickel sulphate solution for $60 \mathrm{~min}$. A good adhesion was found between the interlayer and the substrate, however, the process includes several steps and data about the heat resistance of the varnish layer was not provided. In addition, the presence of the organic layer may also reduce the electrical properties and heat resistance behaviour of the coated $\mathrm{Mg}$ substrate. In another work, a silver film instead of the Ni-P film was also deposited on top of the organic interlayer thus, providing antibacterial and decorative properties [58].

A zinc phosphate layer was deposited on the AZ91D Mg substrate as an intermediate layer prior to Ni plating [59]. The process included alkaline cleaning, degreasing, rinse, phosphating, rinse, electroless Ni-P deposition, drying then heat treatment at $180^{\circ} \mathrm{C}$ for 2 hours. The phosphate interlayer was achieved in a zinc phosphate bath containing molybdate. As an accelerator, it was found that nitrate and nitrite were effective to accelerate the formation of phosphate coating so that full phosphate coating was achieved in 2-3 minutes. The addition of molybdate in the bath by 2$2.5 \mathrm{~g} / 1$ resulted in a full coverage and in refining of the phosphate coat. The electroless Ni-P deposition on the phosphate coating was undertaken using the plating bath containing sulphate nickel. The presence of molybdate $\mathrm{Na}_{2} \mathrm{MoO}_{4}$ in the phosphating bath had an influence on the microstructure, the phases, and the corrosion resistance. It was found that metallic zinc was present in the phosphate coating and that the addition of molybdate in the phosphating bath resulted in the increase of zinc in the coat. A lot of disperse metallic zinc particles acted as catalyst for the succeeding Ni-P deposition. Consequently, a Ni-P a deposit with dense and fine microstructure was obtained having an acceptable corrosion resistance ( $150 \mathrm{~h}$ in salt spray test without corrosion). A surface hardness of $670 \mathrm{VHN}$ was obtained which increased after heat treatment to $915 \mathrm{VHN}$, which are relatively high values.

An intermediate $\mathrm{Cu}$ layer was applied on the Mg AZ91D alloy, to facilitate the deposition of the Ni-P coating [60]. This layer was deposited using a novel $\mathrm{Cu}$ immersion process in a bath containing $0.67 \mathrm{MCuSO}_{4} 5 \mathrm{H}_{2} \mathrm{O}$ and $3 \mathrm{M} \mathrm{HF}$ followed by a surface sealing process. No details about the process conditions were given. It was found that corrosion behaviour of EN specimens was not governed by the microstructural aspects of the Ni-P deposit but mainly by its morphological and surface compositional aspects such as impurities. The use of bath stabilizers - thiourea and maleic acid - were found to affect the corrosion attack after EN deposition.

A novel Ni based coating, where plasma electrolytic oxidation (PEO) pre-treatment followed by electroless Ni plating was developed to produce pore-free Ni coatings on AZ91 $\mathrm{Mg}$ alloy[ 61]. The sequence of the process included PEO, activation, reduction and final electroless plating. The details were given in a Patent by the authors. PEO layer was found to act as an effective barrier and catalytic layer for the subsequent $\mathrm{Ni}$ plating. This technique resulted in a 
decrease in the corrosion current density in potentiodynamic tests by almost two orders of magnitude compared to the traditional EN coating. In addition, the technique does not use chromium and HF in its pre-treatment, therefore, is more environmental friendly.

Pre-treatment using zinc immersion was previously presented by Gray and Luan [9] and had the disadvantages of the need of a precise control to ensure adequate adhesion, for the use of a copper strike which attacks the zinc layer and the $\mathrm{Mg}$ substrate and for environmental reasons. The conventional zinc immersion procedure [53] was found complicated and the step of plating copper with cyanide harmful to the health and environment. More recently, methods using zinc immersion to form intermediate layer below the electroless Ni Plating have been developed and will be presented in detail in the following sections.

\section{Electroless Plating of Magnesium and its Alloys with Zinc Pre-treatment 1. Experimental coating procedure}

Electroless plating technique was developed and optimized for wrought AZ31 magnesium alloy [62] and modified recently to improve the quality of the coat and to apply it on several wrought magnesium alloys [63-64], namely AZ31B, AE42 and ZRE1. The procedure includes mechanical polishing, ultrasonic cleaning, alkaline cleaning, acid pickling, acid activation, zinc immersion, then electroless Ni-P plating. Details of the solutions and procedure are given in Table 1. The use of nickel sulphate solution in electroless plating has been selected as it was successfully used for plating steel and aluminium surfaces [47-49]. The zincate pre-treatment - also called zinc immersion- has been used to remove the residual oxides and hydroxides and to produce a thin layer of zinc to prevent re-oxidation of the magnesium surface, as reported previously [9]. The substrate becomes catalytically active after the surface oxides are dissolved into the plating bath which made the replacement reaction between the substrate and nickel ion happen.

The surface preparation and pre-treatment prior to electroless coating was found to be of prime importance for a successful coat [63-66]. It is to be noted that some defects in the coat were found such as micropores, blistering and cracking and that these defects disappeared after careful surface preparation and bath optimization applying the modified plating procedure shown in Table 1 .

It was reported earlier by Gray et al [9] that the zinc immersion has to be followed by a cyanide copper strike to create a copper film onto which any metal can be subsequently plated. However, the copper strike has the disadvantage of non uniform deposits and high cost of waste treatment. It was replaced by a zinc electroplating step, creating a uniform zinc film of at least 0.6 micron thick, allowing the formation of adherent plating films- like copper- on the magnesium. The zinc electroplating step could take place either simultaneously with the zinc immersion or in a separate step [9]. In a more recent work on AZ91 [67], it was found that the adhesion between the magnesium and the Ni-P plating layer as well as the corrosion resistance were improved if a zinc transition layer was present. The thickness of this layer was not reported, but it was mentioned that this transition layer was thicker and more compact when the zinc immersion bath contained a proper amount of $\mathrm{Fe}_{3} \mathrm{Cl}$. However, this amount was not clearly determined. Zinc immersion was then followed by zinc electroplating then by electroless Ni-P plating. The details of the procedure are given in Table 2. A main difference between the procedures in Tables 1 and 2 is the zinc electroplating following the zinc immersion, thus resulting in a thick zinc or zinc-iron layer which has proved to improve the adherence and coverage of the Ni-P coat [67].

\section{Coat Surface Roughness}

For the procedure in ref. 64, a relatively smooth Ni-P surface was obtained in all samples with $\mathrm{R}_{\mathrm{a}}$ of less than $1 \mu \mathrm{m}$ in most samples and an $\mathrm{R}_{\mathrm{z}}$ value of 3.4 to $5.8 \mu \mathrm{m}$.

A comparison was made between the surfaces obtained by: 1) electroless Ni-P plating, 2) same then followed by $\mathrm{Ni}$ electroplating, and 3)same as in 2) then followed by bright Ni electroplating [62]. The results indicated that bright electroplating gave the least surface roughness, mirror-like which could be used for decorative purpose, followed by Ni electroplated, then electroless plated 
with stabilizer. Additionally, the surface roughness tended to decrease after the heat treatment process [64].

In the process where a zinc transition layer was applied [67] the results indicated that the zinc alloy films containing Fe were smoother and more compact than pure zinc films and that the Ni-P coating became more compact, but no values of surface roughness were reported.

Table 1: Solutions and processes used in nickel plating [63-64]

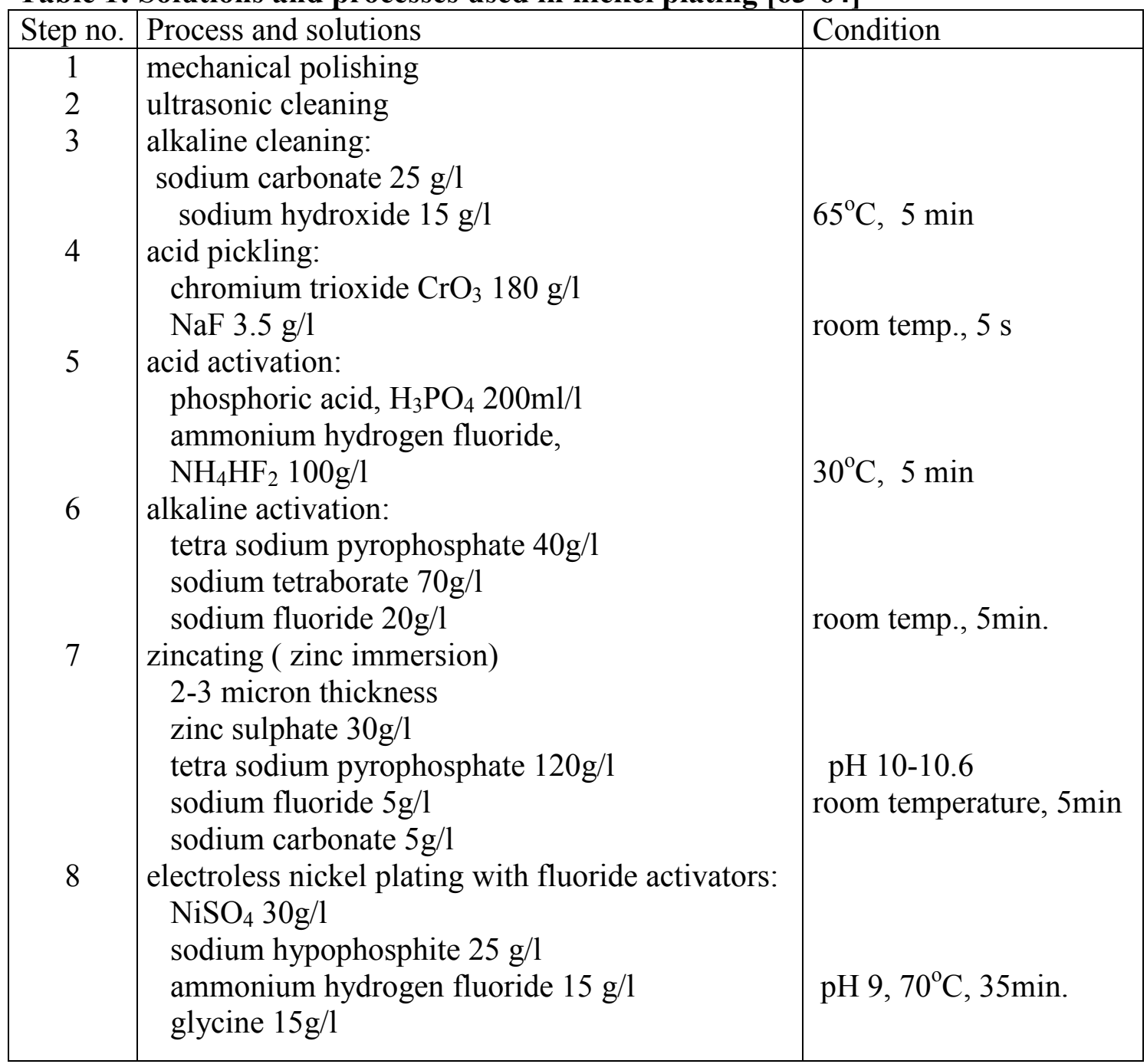

$N B$ : the electroless nickel plating time depends on the thickness needed 
Table 2 The solutions and process flow of electroless nickel plating used in ref [67]

1. ultrasonic cleaning, Acetone degrease

2. acid pickling

$\mathrm{C}_{2} \mathrm{H}_{2} \mathrm{O}_{4} 10 \mathrm{~g} / \mathrm{L}$, Wetting agent, Room Temperature, 1 min

\section{Activation}

$\mathrm{K}_{4} \mathrm{P}_{2} \mathrm{O}_{7} 65 \mathrm{~g} / \mathrm{L}, \mathrm{Na}_{2} \mathrm{CO}_{3} 15 \mathrm{~g} / \mathrm{L}, \mathrm{KF} 7 \mathrm{~g} / \mathrm{L}, 75^{\circ} \mathrm{C}, 2 \mathrm{~min}$

\section{4. immersion zinc}

immersion in $\mathrm{K}_{4} \mathrm{P}_{2} \mathrm{O}_{7}$ zinc bath, $\mathrm{Zn} \mathrm{SO}_{4}-7 \mathrm{H}_{2} \mathrm{O} 50 \mathrm{~g} / \mathrm{L}, \mathrm{K} 4 \mathrm{P} 2 \mathrm{O} 7-10 \mathrm{H}_{2} \mathrm{O}$ 150g/L LiF $3 \mathrm{~g} / \mathrm{L}, \mathrm{Na}_{2} \mathrm{CO}_{3} 5 \mathrm{~g} / \mathrm{L}, \mathrm{pH} 10.2 \sim 10.4,65^{\circ} \mathrm{C}, 3 \mathrm{~min}$

5. electroplating zinc

a) zinc pyrophosphate bath, $\mathrm{Zn}$ salt $21 \mathrm{~g} / \mathrm{L}, \mathrm{K}_{4} \mathrm{P}_{2} \mathrm{O}_{7}-10 \mathrm{H}_{2} \mathrm{O} 260 \mathrm{~g} / \mathrm{L}, \mathrm{C}_{6} \mathrm{H}_{17} \mathrm{O}_{7} \mathrm{~N}_{3} 25 \mathrm{~g} / \mathrm{L}$, thiourea $1 \sim 2 \mathrm{~g} / \mathrm{L}$, luster-coating agent $0.02 \sim 0.05 \mathrm{~g} / \mathrm{L}$

b) zincate bath, $\mathrm{ZnO} 10 \mathrm{~g} / \mathrm{L}, \mathrm{NaOH} 100 \mathrm{~g} / \mathrm{L}$, proper additives, proper luster-coating agent

6. electroless nickel plating

$\mathrm{NiSO}_{4}-6 \mathrm{H}_{2} \mathrm{O} 20 \mathrm{~g} / \mathrm{L}$, HF ( 40\%) $12 \mathrm{~mL} / \mathrm{L}, \mathrm{H}_{3} \mathrm{C}_{6} \mathrm{H}_{5} \mathrm{O}_{7}-2 \mathrm{H}_{2} \mathrm{O} 5 \mathrm{~g} / \mathrm{L}, \mathrm{NH}_{4} \mathrm{HF}_{2} 10 \mathrm{~g} / \mathrm{L}, \mathrm{NH}_{3}-$ $\mathrm{H}_{2} \mathrm{O}(25 \%) 30 \mathrm{~mL} / \mathrm{L}, \mathrm{NaH}_{2} \mathrm{PO}_{2}-\mathrm{H}_{2} \mathrm{O} 20 \mathrm{~g} / \mathrm{L}$, Thiourea $1 \mathrm{mg} / \mathrm{L}, \mathrm{pH} 4.0$, temperature: $95^{\circ} \mathrm{C}$, Time $60 \mathrm{~min}$

7. passivation treatment

$\mathrm{CrO}_{3} 2.5 \mathrm{~g} / \mathrm{L}, \mathrm{K}_{2} \mathrm{Cr}_{2} \mathrm{O}_{7} 120 \mathrm{~g} / \mathrm{L}$, Temperature $90 \sim 100{ }^{\circ} \mathrm{C}$, Time $10 \mathrm{~min}$

Rinse each step

\section{Surface Morphology}

The surface morphology of coated samples following the procedure in Table $1[63,64]$ was studied using the SEM. It was found that the deposit was uniform, defect free, with no pores or cracks, composed of compact fine cauliflower nodules uniform in size with some coarser ones, as shown in Figs. 1 and 2. These nodules consisted of a number of sub-micro nodules which were resolved at higher magnification (Fig. 2). The use of stabilizer in the electroless bath resulted in a slower rate of deposition and the formation of finer uniform nodules more densely packed [62]

The effect of post heat treatment was studied by heating the coated samples in air at $400^{\circ} \mathrm{C}$ for 1 $\mathrm{h}$, then air cooling [64]. After heat treatment (HT), the deposit was similar in shape and quality, but with a smaller amount of cauliflower nodules. This result explained the decrease in surface roughness after HT due to coalescence and coarsening of the nodules[64].

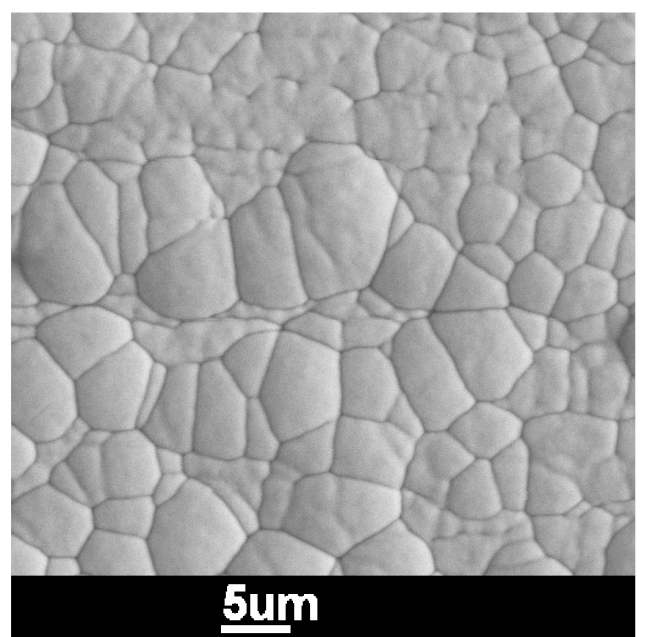

a)

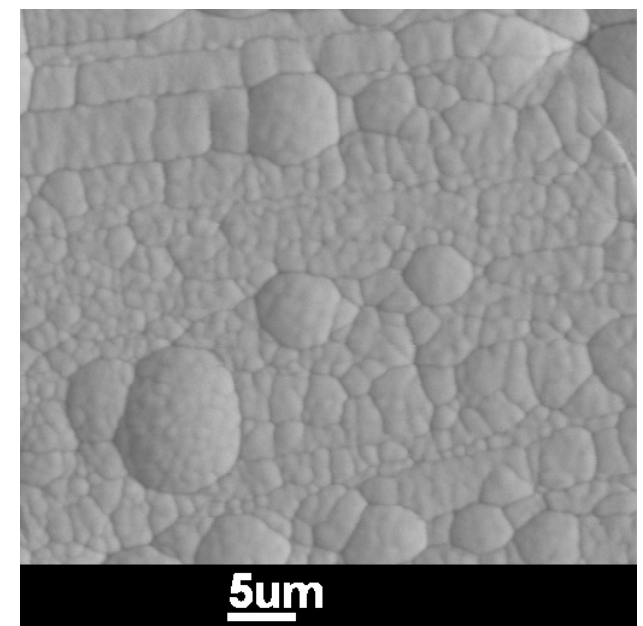

b)

Fig. 1: Surface morphology of coated ZRE1, samples: a) before HT and b) after HT [64] 


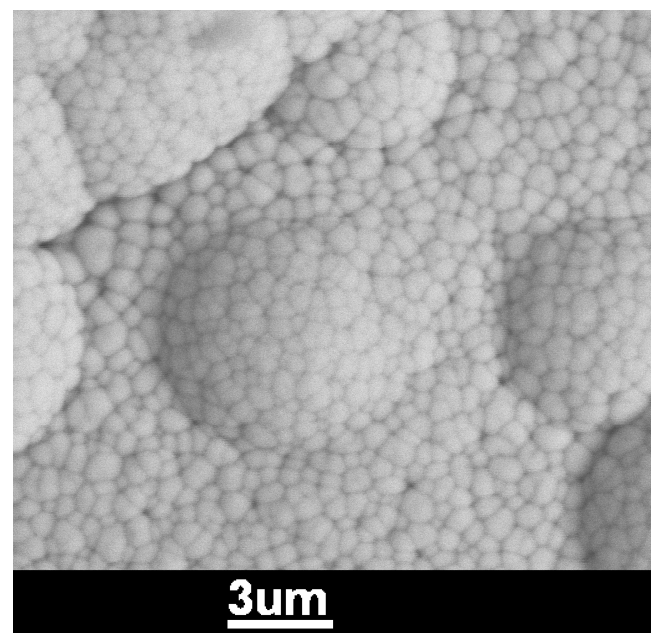

Fig. 2: Surface morphology of $A E 42$ after heat treatment, $X=5000$, showing fine sub- micro nodules [64]

The type of structure of the Ni-P deposits was investigated by X-ray diffraction. The results indicated the presence of amorphous and some nano crystals with an approximate grain size of 3 to $5 \mathrm{~nm}$ before heat treatment which increased to 30 to $50 \mathrm{~nm}$ after heat treatment (HT) [ 68]. Previous qualitative observations indicated that finer grain sizes - on micro-scale - were obtained on steel surfaces in Ni-P deposits with increasing P content [69-70] or with adding $\mathrm{W}$ to the Ni-P deposit [49]. However, no quantitative measurements of the grain size were made. Various structures in the deposit were also obtained such as amorphous [3], amorphous with microcrystals [39], and nano crystals of $\mathrm{Ni}$ and Ni-P compounds. After HT, amorphous $\mathrm{Ni}$ and $\mathrm{P}$ was found to crystallize and form $\mathrm{Ni}_{3} \mathrm{P}$ [3] while a mixture of amorphous and nano crystals separated from each other were also identified [64]. These different results indicate that the formation of amorphous or crystalline phases in the deposit depends on the plating conditions and procedure. It also depends on the $\mathrm{P}$ content as indicated by the results of DSC curves of the deposits in which the microstructure changed from crystalline to amorphous with the increase of $\mathrm{P}$ content [71].

\section{Coat thickness and adhesion}

The coat thickness and adhesion are crucial for a good coat. They were studied by SEM on the cross sections of the coat which was obtained by the procedure in Table 1[64]. Typical micrographs of the sections are given in Fig. 3a, b for AE42 in non heat treated condition and after heat treatment at $400^{\circ} \mathrm{C}$ for $1 \mathrm{~h}$ respectively [64]. The micrographs indicate that in all cases, the coat has a uniform thickness and a good adherence to the magnesium substrates with no defects in the coat or at the interface. It is to be noted that careful surface preparation and increasing the zincating time from 1 to 5minutes improved the adhesion, by eliminating the gap which could be formed at the interface [62]. It is also mentioned that the use of stabilizer for reducing the rate of deposition leads to better adhesion.

The application of a zinc transition layer from a solution containing $\mathrm{Fe}_{3} \mathrm{Cl}$ before the electroless plating of Ni-P,- procedure in Table 2- [67], was found to give a good adhesion and coverage on the $\mathrm{Mg}$ substrate. Unfortunately, no values of layers thicknesses were reported. For obtaining an adequate transition layer, electroplating for at least 10 minutes should follow the zinc immersion step. This step improved the adhesion and reduced the porosity of the zinc layer. In general, an ideal transition layer should be compact with complete coverage of the substrate, with no pin holes and with good adhesion to the subsequent metal plating. An improper transition layer will result in a poor Ni-P coat and may result in corrosion in harsh environments. 


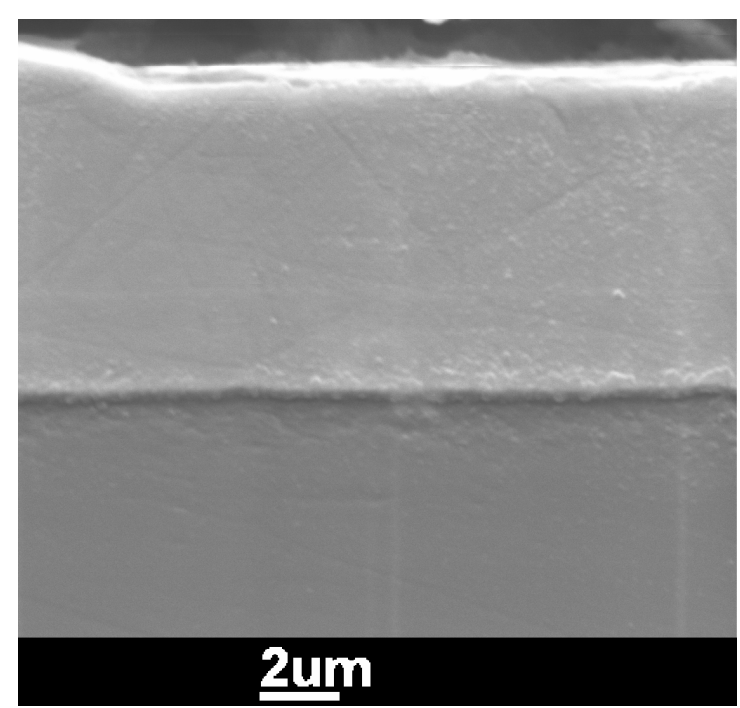

a)

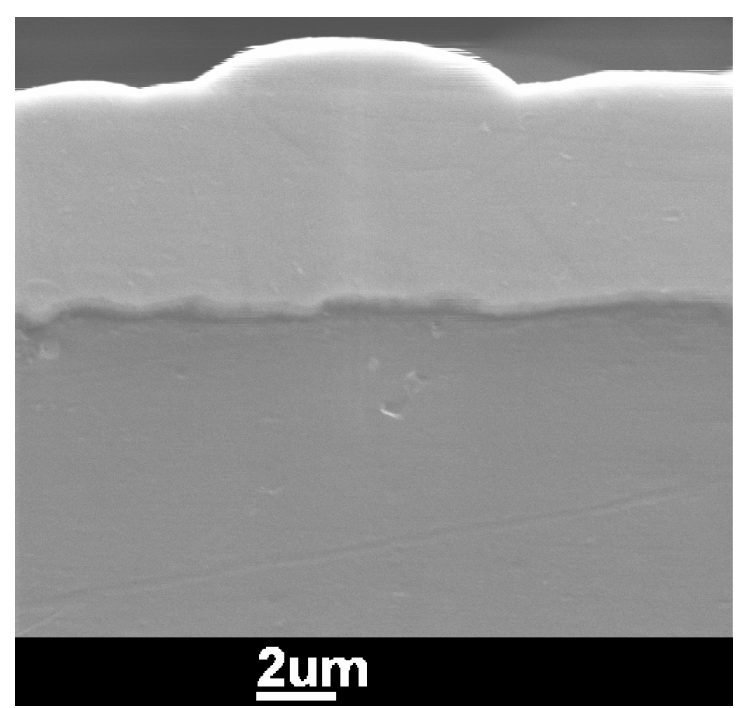

b)

Fig. 3: Photomicrographs of cross sections illustrating the coat and substrate in AE42 samples: a), non heat treated, b) heat treated samples at $400^{\circ} \mathrm{C}$ for $1 \mathrm{~h}$.[64]

The coat thickness is usually function of the rate of deposition - for a given plating time - which depends on the bath and plating conditions $[46,72]$ and complexing agents [61]. The high $\mathrm{pH}(=9)$ used in [64] was more favorable for $\mathrm{Mg}$ alloys because the etch rate decreases with increase in $\mathrm{pH}$. For the procedure in Table 1, the coat thickness for the different $\mathrm{Mg}$ alloys [55] ranged between 9 $\mu \mathrm{m}$ [64] and $29 \mu \mathrm{m}$ [62] for 30 to 35 minutes plating time depending on the alloy type, being maximum for AE42 and minimum for ZRE1and on the bath and plating conditions. Further study relating the growth of the coat to the bath conditions and to the substrate composition is still needed.

\section{Distribution of elements in the coat by EDX analysis}

The chemical analysis of the coat is one of the parameters that determine the chemical, physical and mechanical properties of the coat. $\mathrm{P}$ is usually added to the $\mathrm{Ni}$ bath in order to increase the hardness and wear resistance by forming $\mathrm{Ni}_{3} \mathrm{P}$ after heat treatment.

EDX analysis made on cross sections prepared as given in Table 1, indicate that $\mathrm{Pwt} \%$ in the coat ranges between 1.9 and 9.97\%. [62]. More detailed measurements [64] of $\mathrm{P}$ across the interface, indicated that the phosphorous content increased gradually from the substrate towards the surface and exceeded $10 \mathrm{wt} \%$ as shown in Figs. 4 and 5 for different substrate alloys with no sensitive effect of heat treatment on P redistribution. Fig. 6 also indicates that, as the coat thickness increases, the maximum $\mathrm{P}$ content obtained on the coat surface increases [64]. The increase in P content may result from the variation of the $\mathrm{pH}$ of the solution adjacent to the coating, leading to a change in potential of the substrate associated with increasing bath acidity, hence, $\mathrm{P}$ content in the deposit [73].

Previous work [71] indicates that the $\mathrm{P}$ content in the deposit depends on bath temperature, composition and plating conditions and with increasing bath $\mathrm{pH}[48,72]$. The $\mathrm{pH}$ of the bath may also change during coating, which may also affect the $\mathrm{P}$ content during the coating. In addition, the substrate alloy is thought to affect the $P$ content as the activation of the substrate is dependent on the alloy composition as the plating conditions were kept constant in [64]. The alloy composition of the substrate and its structure were previously found to affect the structure of the deposit by affecting the nucleation and growth mechanisms [74], however, no previous study on its effect on the chemical composition of the deposit was found available. 
Some magnesium was also found in the coat of the different alloys, ranging from 1 to $2 \%$ on the surface and increasing towards the substrate, reaching 4 to 6\% [64]. The large amount of magnesium at the interface suggested a probable formation of $\mathrm{Ni}-\mathrm{Mg}$ intermetallic phase, which may enhance the adhesion to the substrate.

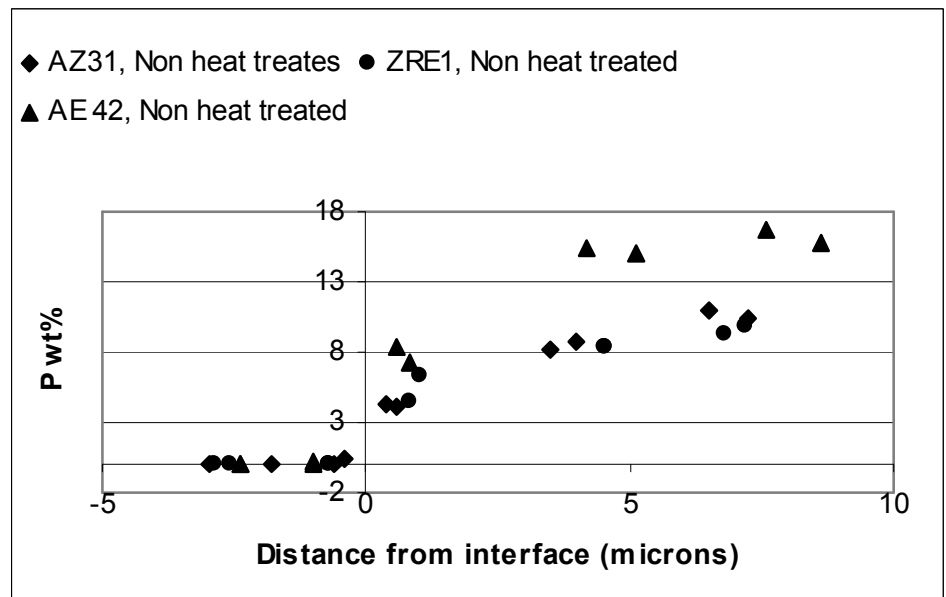

Fig. 4: Phosphorous distribution from the substrate towards the coat surface in not heat treated condition for different Magnesium alloys [64]

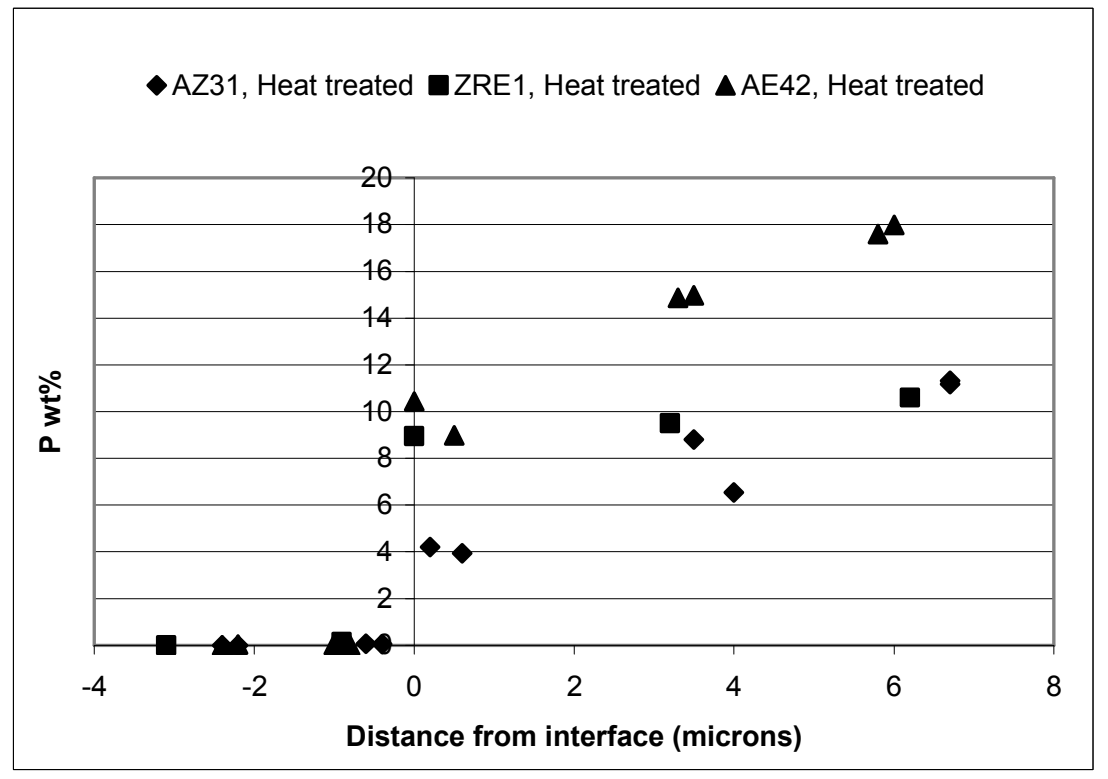

Fig. 5: Phosphorous distribution from the substrate towards the coat surface for different Magnesium alloys; heat treated [64] 


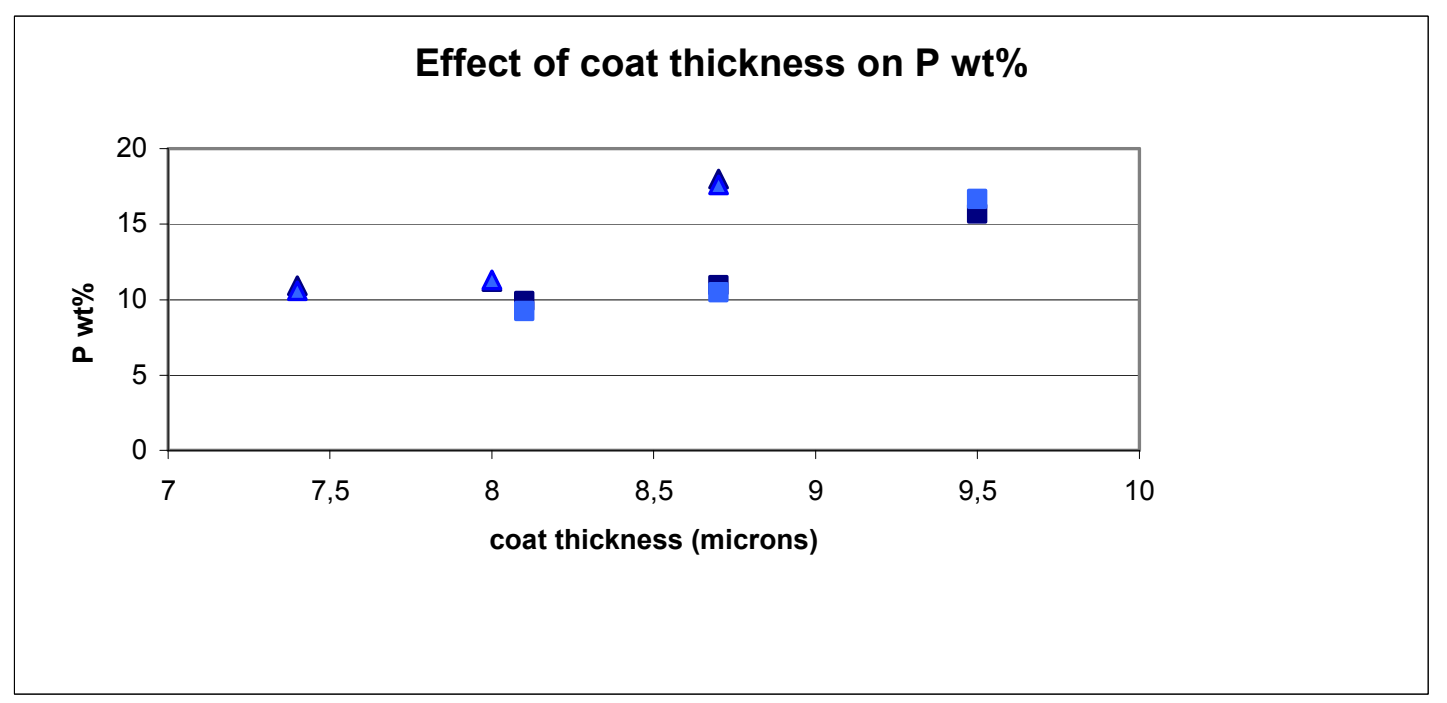

Fig. 6: Effect of coat thickness on the phosphorous content on the surface of the substrates before and after heat treatment [64]

\section{Coat Hardness}

In general, it is advantageous to reach a high hardness in the as coated soft products such as plastics, aluminium, magnesium and printed circuits which cannot be subjected to post heat treatment. For Mg substrates, the hardness increases after deposition of Ni-P coat due to the higher hardness of the latter. It is also known that the hardness of Ni-P increases with increasing P content in the coat [46] where a maximum value of $650 \mathrm{HV}$ could be reached for the coat containing more than $10 \mathrm{wt} \% \mathrm{P}$ in the as-coated deposit on steel substrate. Additionally post heat treatment raises the hardness of the coat due to the precipitation or agglomeration of $\mathrm{Ni}_{3} \mathrm{P}$ after heat treatment $[62,46$, 48, 49 and 75]. This is illustrated in Fig. 7 [63] for AZ31 alloy which indicates the increase in hardness with $\mathrm{P}$ content and with heat treatment.

Additional elements to the bath can also raise the hardness such as tungsten or cobalt [76] due to the formation of supersaturated solid solution, even with the presence of low $\mathrm{P}$ content in the deposit [13]. Also the addition of fluoborate anions in the bath with concentration up to 0.04 Mole corresponding to $7.6 \mathrm{wt} \% \mathrm{P}$ - resulted in increasing the hardness due to inhibition of crystal growth during deposition thus producing finer and more homogeneous grains [48]. However, no quantitative measurements of the grain size were given. In general, the hardness was found to depend on bath composition, plating parameters and concentration of ammonium- bifluoride. These results indicate that it is possible to reach the required selected hardness by proper control of the bath and plating conditions. However, a good documentation of the plating parameters and their effect on hardness are still needed. 


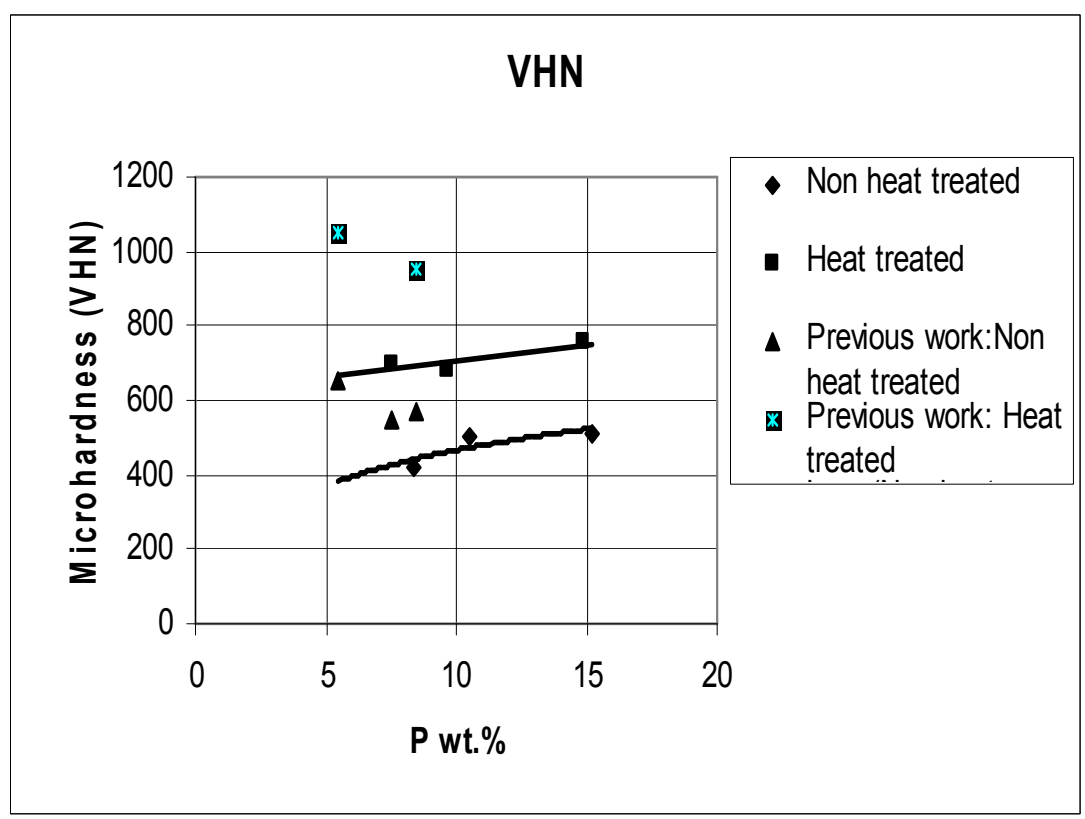

Fig. 7: Effect of $\mathrm{P} w t \%$ on the micro-hardness of the coat in as deposited and after heat treatment conditions. Non heat treated and heat treated refer to the Ni-P coat on Mg AZ31 [64].

\section{Electrochemical Test Results}

For the magnesium alloy samples in the as-coated condition using unmodified procedure, the humidity test revealed the presence of some corrosion spots and blistering $[62,63]$.

Potentiodynamic polarisation tests carried out at $(25 \pm 1)^{\circ} \mathrm{C}$ on the samples prepared by the modified procedure in Table 1 [63] tested in $3 \% \mathrm{NaCl}$ solution gave the curves shown in Fig. 8 for the bare, electroless $\mathrm{Ni}$ coated, and heat treated after coating ZRE1 Mg alloys. The results illustrated that, regardless the effect of heat treatment, the coat gave the noble corrosion potential $\left(\mathrm{E}_{\text {corr }}\right)$ values characteristic of the Ni-P layer and with significantly low corrosion current densities $\left(\mathrm{I}_{\text {corr }}\right)$, and that heat treatment further improved the corrosion resistance, Table 3 , where $\mathrm{E}_{\text {corr }}$ and $\mathrm{I}_{\text {corr }}$ reached $-228 \mathrm{mV}$ and $0.95 \mu \mathrm{A} / \mathrm{cm}^{2}$ respectively, which are very low values. Additionally, the coat layer was resistant to atmospheric corrosion, as indicated by the humidity test [63].

In order to reduce the effect of the galvanic cell which can be encountered once corrosion begins in porous areas of the deposit, a thicker zinc transition layer was applied between the substrate and the Ni-P layer using electrodeposition of zinc after zinc immersion as indicated in Table 2 [67]. The zinc layer reduced the difference in potential between the noble nickel and the active magnesium. The adhesion and corrosion results of the Ni-P coatings, shown in Table 4, indicate an improvement in the adhesion and the absence of corrosion spots in the case of applying the zinc immersion process in a solution containing $\mathrm{Fe}_{3} \mathrm{Cl}$ followed by 10 minutes zinc electroplating. The application of zinc electroplating improved further the quality of Ni-P coating by covering the pin holes. This is indicated by the potentiodynamic polarization curves which showed a shift towards a more positive corrosion potential reaching $-800 \mathrm{mV}$ for the zinc/Ni-P coat as shown in Fig.9.

The results of corrosion potential and corrosion current densities obtained by several workers in recent publications applying electroless Ni-P plating using different techniques, solutions and /or pre-treatments are summarized in Table 5. The results indicate that several solutions and processes can protect the $\mathrm{Mg}$ substrate, and that the zinc immersion technique in Table 3 and the zinc transition layer methods in Table 5 are among the promising techniques. A thicker pore-free protection layer may be preferable as it decreases the probability of the presence of open pores. 
Table 3 Electrochemical parameters of bare, electroless Ni coated, and heat treated after coating of AE42 and ZRE1, obtained by polarisation in $3 \% \mathrm{NaCl}$ solution [64]

\begin{tabular}{|l|c|c|c|}
\hline Sample & OCP, $\mathrm{mV}$ & $E_{\text {corr }}, \mathrm{mV}$ & $\mathrm{I}_{\text {corr, }} \mu \mathrm{A} / \mathrm{cm}^{2}$ \\
\hline AE42-Mg alloy & $\mathbf{- 1 6 0 1}$ & $\mathbf{- 1 5 3 5}$ & $\mathbf{1 5 . 7 7}$ \\
\hline Coated AE42 & $\mathbf{- 4 6 3}$ & $\mathbf{- 4 7 4}$ & $\mathbf{0 . 7 5}$ \\
\hline ZRE1-Mg alloy & $\mathbf{- 1 5 5 4}$ & $\mathbf{- 1 5 1 8}$ & $\mathbf{7 5 . 2 4}$ \\
\hline Coated ZRE1 & $\mathbf{- 1 1 8 8}$ & $\mathbf{- 1 2 1 0}$ & $\mathbf{3 8 0 . 5 9}$ \\
\hline HT coated ZRE1 & $\mathbf{- 2 1 7}$ & $\mathbf{- 2 2 8}$ & $\mathbf{0 . 9 5}$ \\
\hline
\end{tabular}

Table 4. Effect of zinc transition layer on adhesion and corrosion of nickel plating [67]

\begin{tabular}{|c|c|c|c|c|c|}
\hline \multirow[t]{2}{*}{ Test } & \multirow[t]{2}{*}{ Zinc immersion operation } & \multirow[t]{2}{*}{$\begin{array}{l}\text { Electroplating } \\
\text { zinc time/ min }\end{array}$} & \multirow[t]{2}{*}{ adhesion } & \multicolumn{2}{|c|}{$\begin{array}{l}\text { Corrosion spots of Ni-P } \\
\text { coating }(\mathrm{cm}-2)\end{array}$} \\
\hline & & & & $15 \mathrm{~h}$ & $30 \mathrm{~h}$ \\
\hline 1 & No immersion & 0 & $\mathrm{X}$ & 2.01 & $\begin{array}{l}\text { perfect } \\
\text { corrosion }\end{array}$ \\
\hline 2 & $\begin{array}{l}\text { Immersion once( the bath } \\
\text { with } \mathrm{Fe}^{3+} \text { ) }\end{array}$ & 0 & $\mathrm{O}$ & 0 & 0.32 \\
\hline 3 & No immersion & 10 & $X$ & $\begin{array}{l}\text { Perfect } \\
\text { corrosion }\end{array}$ & \\
\hline 4 & No immersion & 40 & $\mathrm{O}$ & 0 & 0 \\
\hline 5 & $\begin{array}{l}\text { Immersion once (the bath } \\
\text { with } \mathrm{Fe}^{3+} \text { ) }\end{array}$ & 10 & $\mathrm{O}$ & 0 & 0 \\
\hline
\end{tabular}

Note: "X" stands for very poor adhesion and plating continuously sloughed-off.

"O" represents good quality plating without swell and peel off

Table 5. Potentiodynamic polarization measurements of electroless Ni plating (EN) using different pre-treatments/ techniques in about 3.5- $5 \mathrm{wt} \% \mathrm{NaCl}$ solution

\begin{tabular}{|c|c|c|c|c|}
\hline Technique & $\begin{array}{l}\text { Ecorr } \\
\mathrm{mV}\end{array}$ & Icorr $\mu \mathrm{A} / \mathrm{cm}^{2}$ & comments & reference \\
\hline $\begin{array}{l}\text { Bare AZ91D } \\
\text { Zinc transition coating } \\
\text { Zn/Ni-P coat }\end{array}$ & $\begin{array}{l}-1450 \\
-1150 \\
-800\end{array}$ & & $\begin{array}{l}\text { Zinc transition layer } \\
\text { provides highly } \\
\text { compact Ni-P coat, } \\
\text { strong adhesion }\end{array}$ & 67 \\
\hline $\begin{array}{l}\text { Uncoated AZ91 } \\
\text { Traditional EN } \\
\text { Plasma electrolytic oxidation } \\
(\text { PEO) + EN }\end{array}$ & $\begin{array}{l}-1500 \\
-300 \\
-300\end{array}$ & $\begin{aligned} & \sim 10 \\
& \sim 2.0 \\
& \sim 0.07\end{aligned}$ & $\begin{array}{l}\text { EN with } 25 \mu \mathrm{m} \text { for PEO } \\
+\mathrm{EN}: \text { less porosity, } \\
\text { better corrosion } \\
\text { resistance than EN, no } \\
\text { noticeable pits after } \\
168 \mathrm{~h} \text { in salt spray. }\end{array}$ & 61 \\
\hline $\begin{array}{l}\text { AZ31 bare } \\
\text { EN plated for } 60 \mathrm{~min} \text { in } \\
\text { sulphate solution }\end{array}$ & $\begin{array}{l}\sim-1569 \\
\sim-1316\end{array}$ & $\begin{array}{l}10 \\
0.10\end{array}$ & $\begin{array}{l}\text { Organic coating+ } \\
\text { Electroless plating }\end{array}$ & 53 \\
\hline Organic layer + silver plating & & & $\begin{array}{ll}\text { Improvement } & \text { in } \\
\text { corrosion resistance } & \end{array}$ & 58 \\
\hline $\begin{array}{l}\text { AZ31 } \\
\text { Organic layer }+\mathrm{Cu} \text { plated for } \\
60 \mathrm{~min}\end{array}$ & $\begin{array}{l}-1569 \\
-1368\end{array}$ & $\begin{array}{l}30 \\
\sim 100\end{array}$ & $\begin{array}{l}\text { A shift in about } 200 \\
m V \text { in } E_{\text {corr }}\end{array}$ & 77 \\
\hline $\begin{array}{l}\text { AZ31 } \\
\text { Substrate with Ni -P layer }\end{array}$ & $\begin{array}{l}-1502 \\
-781\end{array}$ & $\begin{array}{l}411.8 \\
17.79\end{array}$ & $\begin{array}{l}\text { Further improvement } \\
\text { with Ni-Sn-P }\end{array}$ & 78 \\
\hline
\end{tabular}




\begin{tabular}{|c|c|c|c|c|}
\hline Substrate with Ni-Sn-P & -645 & 5.29 & & \\
\hline $\begin{array}{l}\text { Multi layer coat on AZ91 } \\
\text { Ni-P-ZrO2 } \\
\text { And } \\
\text { Ni-P electroplating }\end{array}$ & & & $\begin{array}{l}\mathrm{ZrO}_{2} \text { nano crystals } \\
\text { gave superior corrosion } \\
\text { properties } 1000 \mathrm{~h} \text { in salt } \\
\text { spray test }\end{array}$ & 79 \\
\hline $\begin{array}{l}\text { AZ91D } \\
\text { Ni-W-P }(24 \mu \mathrm{m}) \\
\text { Ni-P }(28 \mu \mathrm{m})\end{array}$ & $\begin{array}{l}-1569 \\
-701 \\
-781 \\
\end{array}$ & $\begin{array}{l}411.8 \\
7.8 \\
17.79 \\
\end{array}$ & $\begin{array}{l}\text { Improvement in } \\
\text { corrosion resistance for } \\
\text { the ternary system }\end{array}$ & 80 \\
\hline $\begin{array}{l}\text { AZ91D } \\
\begin{array}{l}\text { Substrate with } \\
\text { electroless Ni coat } \\
\text { Same but } 25 \mu \mathrm{m} \text { electroless Ni }\end{array} \\
\begin{array}{l}\text { Substrate with } 10 \mu \mathrm{m} \\
\text { electroless } \mathrm{Ni} \text { coat }+ \\
\text { electroplating of nano } \\
\text { crystalline } \mathrm{Ni}\end{array}\end{array}$ & $\begin{array}{l}-1500 \\
-1420 \\
-410\end{array}$ & $\begin{array}{l}1546 \\
327 \\
9.8\end{array}$ & $\begin{array}{l}\text { increase in thickness of } \\
\text { electroless Ni } \\
\text { improved the corrosion } \\
\text { behaviour } \\
\text { Nano crystals of Ni by } \\
\text { DC electroplating had } \\
\text { the lowest current } \\
\text { density due to fine } \\
\text { grains and low porosity } \\
\text { in nano crystals }\end{array}$ & 81 \\
\hline $\begin{array}{l}\text { AZ91D } \\
\text { Different EN plating solutions } \\
\text { for minimum porosity: } \\
\text { hypophosphite/basic nickel } \\
\text { carbonate } 1.75 \text { - fluoride } 25 \mathrm{~g} / 1 \\
\text { - TU and others }\end{array}$ & & & $\begin{array}{l}\text { A remarkable influence } \\
\text { of plating parameters } \\
\text { on porosity and } \\
\text { thickness of plating } \\
\text { coat electroless Ni } \\
\text { deposits on AZ91D }\end{array}$ & 82 \\
\hline $\begin{array}{l}\text { AZ91D } \\
\text { EN Ni-P } \\
\text { Ni-P/Ni-B duplex coat with } \\
\mathrm{Ni-B} \text { outer layer }+ \text { heat } \\
\text { treatment at } 350^{\circ} \mathrm{C} 2 \mathrm{~h}\end{array}$ & $\begin{array}{l}-1502 \\
-653\end{array}$ & $\begin{array}{l}411.8 \\
3.97\end{array}$ & $\begin{array}{lr}\text { Duplex } & \text { coating, } \\
\text { provides a } & \text { physical } \\
\text { barrier } & \text { against } \\
\text { corrosion } & \text { attack, } \\
\text { provides a sacrificial } \\
\text { protection for the inner } \\
\text { Ni-P coat , hence } \\
\text { improves corrosion } \\
\text { resistance }\end{array}$ & 83 \\
\hline $\begin{array}{l}\text { AZ91 } \\
\text { With chemical conversion } \\
\text { coat }(\mathrm{CC}) \\
\mathrm{CC}+\mathrm{Ni}-\mathrm{P}\end{array}$ & $\begin{array}{l}-1550 \\
-1400 \\
\sim-600 \\
\end{array}$ & & $\begin{array}{l}\text { Remarkable decrease } \\
\text { in } \mathrm{E}_{\text {corr }} \text { and } \mathrm{I}_{\text {corr }} \text { after } \\
\mathrm{CC}+\mathrm{EN}\end{array}$ & 57 \\
\hline $\begin{array}{l}\text { AZ91 } \\
\text { phosphate manganese pre- } \\
\text { treatment }(\mathrm{Cr} \text {-free) } \\
\text { Ni-P layer after pre-treatment } \\
\text { in Hexavalent chromium and } \\
\text { HF solution } \\
\text { Ni-P on Cr- free pre-treatment }\end{array}$ & $\begin{array}{l}-1502 \\
-1442\end{array}$ & $\begin{array}{l}411.8 \\
48.91\end{array}$ & $\begin{array}{l}\text { Chromium - free pre- } \\
\text { treatment is successful } \\
\text { for further EN plating }\end{array}$ & 56 \\
\hline $\begin{array}{l}\text { AZ91D } \\
\text { Zinc phosphate pre- } \\
\text { treatment+EN }\end{array}$ & & & $\begin{array}{l}\text { Withstand } 150 \mathrm{~h} \text { in salt } \\
\text { spray test without } \\
\text { corrosion }\end{array}$ & 59 \\
\hline $\begin{array}{l}\text { AZ31 } \\
\text { EN + mechanical attrition }\end{array}$ & $\begin{array}{l}\sim-1450 \\
\sim-200 \\
\end{array}$ & & $\begin{array}{l}\text { Mechanical attrition } \\
\text { during EN gave further }\end{array}$ & 55 \\
\hline
\end{tabular}




\begin{tabular}{|c|c|c|c|c|}
\hline $\mathrm{EN}+$ heat treatment & $\sim-1250$ & & $\begin{array}{l}\text { improvement in } \\
\text { corrosion resistance } \\
\text { compared to traditional } \\
\text { EN }\end{array}$ & \\
\hline $\begin{array}{l}\text { AZ91D } \\
\text { EN } \\
\mathrm{EN}+\text { heat treatment } 230^{\circ} \mathrm{C}, 2 \mathrm{~h} \\
\mathrm{EN}+\text { heat treatment } 400^{\circ} \mathrm{C}, 1 \mathrm{~h}\end{array}$ & $\begin{array}{l}\sim-1320 \\
-450 \\
-450 \\
-980\end{array}$ & $\begin{array}{l}800 \\
90 \\
120 \\
230\end{array}$ & $\begin{array}{l}\text { Heat treatment has no } \\
\text { effect on corrosion } \\
\text { potential but a slight } \\
\text { change in corrosion } \\
\text { current }\end{array}$ & 84 \\
\hline
\end{tabular}

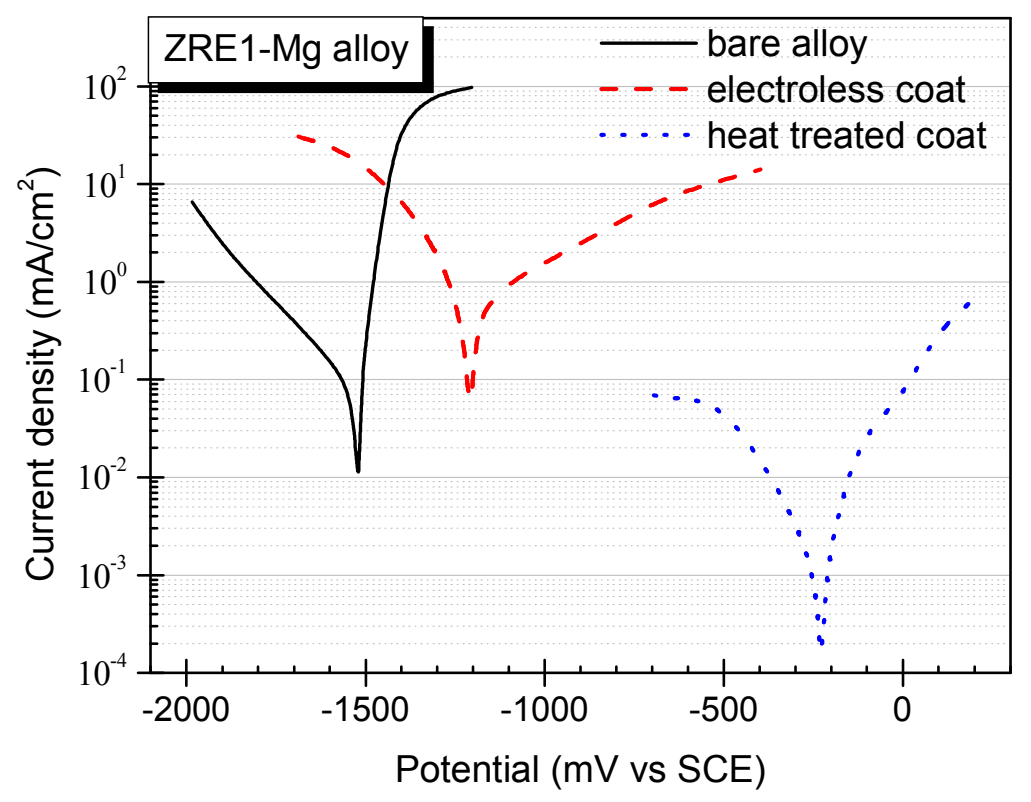

Fig. 8: Potentiodynamic polarisation diagrams for $\mathrm{ZRE} 1$ in $3 \% \mathrm{NaCl}$ solution for bare, electroless $\mathrm{Ni}$ coated, and heat treated at $400{ }^{\circ} \mathrm{C} 1 \mathrm{~h}$ after coating [64].

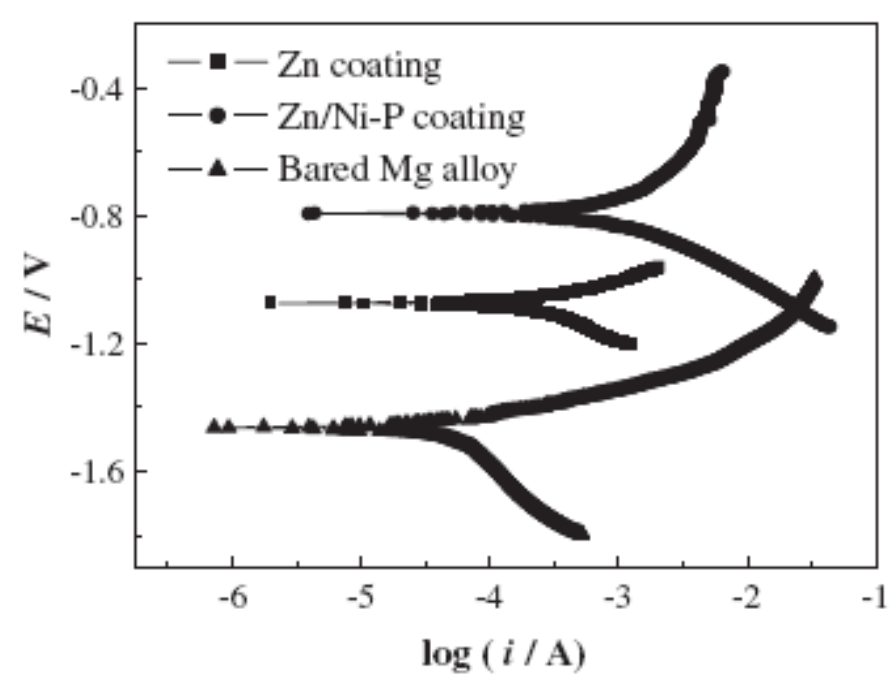

Fig. 9: Potentiodynamic polarisation curves of the bare magnesium alloy, zinc coating and Zn/Ni-P coating using a zinc transition layer [67]. 


\section{Conclusions}

Coating of different magnesium alloys, was achieved successfully by electroless Ni-P (EN) plating from a sulphate solution and a zinc pre-treatment. Two techniques were presented for pre-treatment; the first using zinc immersion for 5 minutes prior to EN plating; the second using zinc transition layer prior to the EN plating. The zinc immersion was obtained from a zinc sulphate solution, while the zinc transition layer was obtained by zinc immersion followed by 10 minutes DC zinc electroplating. The thickness of the zinc transition layer was larger than that of zinc immersion resulting in a better closing of pores.

The deposited Ni-P coat contained a mixture of amorphous and nano crystalline materials with $\mathrm{Ni}$ and Ni-P mixture, while after heat treatment (HT) at $400{ }^{\circ} \mathrm{C}$ for 1 hour Ni-P compounds were formed.. The deposit was compact, uniform in thickness, without detectable defects or porosity and with good adhesion to the substrates, before and after HT. The P content in the coat was found to increase with coat thickness which resulted in an increase in microhardness which ranges between 420 and $512 \mathrm{HV}$ for as coated and between 700 and $760 \mathrm{HV}$ after HT.

The corrosion behaviour of electroless Ni-P based on potentiodynamic polarization tests in chloride solution indicated a large improvement compared to that of bare magnesium alloys in case of pre-treatments with zinc immersion where $E_{\text {corr }}$ reached $-474 \mathrm{mV}$ and $\mathrm{I}_{\text {corr }} 0.75 \mu \mathrm{A} / \mathrm{cm}^{2}$. More noble behaviour was obtained after $\mathrm{HT}$ where $\mathrm{E}_{\text {corr }}$ reached $-228 \mathrm{mV}$ and $\mathrm{I}_{\text {corr }} 0.95$ $\mu \mathrm{A} / \mathrm{cm}^{2}$. When pre-treatment produced the zinc interlayer, the thickness of the zinc layer was increased and $\mathrm{E}_{\text {corr }}$ reached $-800 \mathrm{mV}$.

Therefore, the electroless Ni (EN) plating preceded by zinc immersion or zinc transition -by electroplating- are among the most promising techniques for coating of $\mathrm{Mg}$ alloys. The procedure is simple and provides good corrosion resistance and relatively high hardness.

\section{References}

[1] B. Landkof: Proc. Magnesium Alloys and their Applications, ed. K.U. Kainer, Wiley VCH Verlag, Weinheim (2000), p.168-172

[2] A.K. Sharma, R. Uma Rani , K. Giri: Metal Finishing, vol. 95 (3), (1997), p.43-46, 48-51.

[3] A.K. Sharma, M.R. Suresh, H. Bhojraj, H. Narayanamurthy and S.P. Sahu, ISRO Satellite Centre, Bangalore, India, Metal Finishing, March (1998), p.10-18.

[4] G. Spur, T. Stoeferle: Handbook der Fertigungstechnik, Bd. 4/1, Abtragen, beschichten, Carl Hanser Verlag, Munchen Wien, (1987), p. 342-59.

[5] G. Bockmair, P. Kurze: Proc. Conf. Magnesium Alloys and their Applications,[ed.: B.L.Mordike and K.U.Kainer], Frankfurt an Main, MAT-INFO WerkstoffInformationsgesellschaft, (1998), p.421-25.

[6] M.A. Gonzalez-Nunez, C.A., Nunez-Lopez, P. Skeldon, G.E. Thompson, H. Karimzadeh, P., Lyon and T.A. Wilks: Corrosion Science 37, (1995), No 11, p.1763-22.

[7] E.H. Han, W. Zhou and D.K.W. Shan: Mater. Science For. 419-422, (2003), p. 879-82.

[8] D. Hawke and D.L. Albright: Metal Finishing 93 No 10, (1995), p. 34-38.

[9] J.E. Gray and B. Luan: J. Alloys and Compunds 336, (2002), p. 88-113.

[10] H. Umehara S Terauchi and M. Tayaka: Mat Sci. For. 350/351, (2000), p. 273-82. 
[11] H. Umehara, M. Tayaka and Y. Kojima: Mater. Trans. 42 , (2001), No 8, p. 1691-99.

[12] A. Chino, Y. Mori, K. Ippongi and M. Mabuchi: Mat.Trans.43, No 3, (2002), p.340-42.

[13] H.Zhang Yao, and G.Liu Yihan: Material Review, vol. 21 No 3, (2007), p. 77-80.

[14] G. Reiners and M. Griepentrog: Surface Coating Technology 76/77, (1995), No 1/3, p. 809-14.

[15] A. Yamamoto, A. Watanabe, K. Sugahara, H. Tsubakino and S. Fukumoto: Scr. Mater. 44, (2001), p. 1039-42.

[16] A. Yamamoto and H. Tsubakino: Mater. Scie. For. 419/422, (2003), p. 903-08.

[17] S.Langelfeld, G. Jonschker and H. Schmidt: Materialwissenschaft und Werkstofftechnik 29, (1998), p. 23-29.

[18] M. Weisheit, U. Lenz, B. Mordike : Metall 51, No 9, (1997), p. 470-74

[19] A. Tsubakino, A. Yamamoto, A. Watanabe and S. Fukumoto: Materials Week 2001, Proc. Intern. Congress on Advanced Materials, their Processes and Applications, Munchen, (2001), p.1-6.

[20] C. Gu, J. Lian and Z.Jiang, Advanced Engineering Materials, 7(2005)11, p.1032 - 1036 .

[21] Ma Youping, Xu Kewei, Wen Weixin, He Xipeng and Liu Pengfei; Surface Coatings \& Technology, 190, (2005), p. 165-170.

[22] B. Wielage, K. Fleisher, R. Zenker and S. Schammer: Proc. Conf. On Magnesium Alloys and Their Applications, ed. B.L. Mordike and K.U Kainer, Werkstoff_Informationsgesellshaft, (1998), p. 427-31.

[23] R. Galun, A. Weisheit, B.L. Mordike: Proc. Conf. On Magnesium Alloys and Their Applications, ed. B.L.Mordike and K.U. Kainer, Werkstoff-Informationsgesellschaft, (1998), p. 439-44.

[24] T. Maiwald, R. Galun, B.L. Mordike and F.J.Feikus: Lasers in Eng. 12, No 4, (2002), p. 227-38.

[25] K.U. Kainer ed. : Proc. $6^{\text {th }}$ Intern. Conf. Magnesium Alloys and Their Applications, Wolfsburg, DGM-VCH Verlag GmbH, (2004).

[26] A. Berkani, P. Skeldon, G.E. Thompson, K. Shimizu, H. Habazaki, H. Karinzadeh, K. Stevens, C. John: ibid, p. 592-98.

[27] S. Hutchins, P. Shshkov, V. Sansonov and A. Shatrov. Ibid, p. 553-58.

[28] D.E. Bartak, T.D. Scleisman, E.R. Woolsey: $16^{\text {th }}$ Intern. Die Casting Congress and Exhibition, River Grove, USA, North America Die Casting Association , Trans., (1991), p. 97-100. 
[29] P. Kurze and D. Banejee: Giesserei Praxis, No 11/12, (1996), p. 211-17.

[30] P. Kurze : Metalloberflaesche 48, No 2, (1994), p. 104-105.

[31] S. Hutchins, S. Shrestha, A. Sturgeon, , P. Shatrov, A.Shatrov: Magnesium, Proc $6^{\text {th }}$ Int. conf. Magnesium Alloys and their Applications, K.U.Kainer, ed. DGM, WileyVCH Verlag GmbH, (2004) ,p. 617-22.

[32] H.M. Nykyforchyn, M. D. Klapkiv, W. Dietzel, C. Blawert: ibid. p. 176-81.

[33] B. Valeriy, I. Sergey, M. Anna, S. Valeriya: ibid. p. 540-43.

[34] R. Gagow, D. Scherer, C.C. Stahr: ibid. p. 548-52.

[35] E. Lugscheider, M. Parco, K.U. Kainer, N.Horst: ibid. p. 860-68.

[36] V. Neubert, I. Stulikova, B. Smola, B.L. Mordike, M. Vlach, A. Bakkar and J. Pelcova: Materials Science and Eng. A, (2007) v.462, p. 329-33

[37] V. Neubert, A. Bakkar: Magnesium, Proc $6^{\text {th }}$ int. conf. Magnesium Alloys and their Applications, K.U.Kainer, ed. DGM, Wiley-VCH Verlag GmbH, (2004), p. 638-45.

[38] G. Song, A. Atrens, M. Dargusch, Corrosion Science, 41, (1999), p.249.

[39] R. Ambat W. Zhou, Surface \& Coating Technology, 179(2004), p.124-134

[40] W. Froemberg and F.A. S. Donaldson: Advanced Materials and Processes, vol.149, No 2, (1996), p.33-35.

[41] A. Bakkar and V. Neubert: Electrochemistry Ccommunications , vol. 9, (2007), p.2428- 2435

[42] A. Bakkar, R.Galun and V.Neubert, Materials Science and Technology, (2006), v. 22 No 3 p. 353-362.

[43] M Taha, N. El Mahallawy, R.Hammouda, S. Nassef and C. Metzner: in Metals Processing and Manufacturing Conf., MPM 2007, 19-22 Nov.(2007), Cairo, Egypt.

[44] L.H. Chiu, H.A. Lin, C.C. Chen, C.F. Yang, C.H.. Chang and J.C. Wu: Mater. Sci. For. 419/422, (2003), p. 909-14

[45] Y.F. Jiang, C.Q. Zhai, L.F.Liu, Y.P. Zhu, W.J.Ding, Surface \&Coatings Technology, 191, (2005), p. 393-399

[46] M. Shoeib, S. Steinhauser, B. Wielage. A. Grzybech, K H Lange, Proc. of the $15^{\text {th }}$ World Congress and Exhibition, Sept 13-15, (2000), Garmisch-Partenkirchen, Germany, Session 15, p.1-10.

[47] M.M. Younan, M. Shoeib and A Abo El-Enin, Galvanotechnik, 92(2001)6, p. 1531-1538.

[48] M. A. Shoeib, Galvanotechnik, 94(2003)3, p. 588-593. 
[49] M.M. Younan and M. Shoeib, Galvanotechnik, 93(2002)4, p. 932-937.

[50] A. Tan, A. Soutar, I. Annergren and Y. Liu, Surface \& Coatings Techn., 198(2005), p. 478- 482

[51] C. Gu, J. Lian, J He, Z Jiang, Q. Jiang , Surface \& Coating Techn., 200(2006), p. 5413-5418.

[52] C. Gu, J. Lian, G. Li, L. Niu, Z. Jiang, J. Of Alloys and Compounds 391, ( 2005) p. 104-109

[53] H.Zao, Z. Huang, J.Cui, Surface \& Coating Technology, 202, ( 2007) p. 133- 139

[54] J. Li, Z. Shao, X. Zhang, Y. Tian, Surface \& Coating Technology, 200, ( 2006) p. 30103015 .

[55] H.D. He, H.F. Fu, X.G. Li and W. Gao, Scripta Materialia 58 ( 2008) , p.504- 507.

[56] W. X.Zhang, J.G. He, Z.H. Jiang, Q. Jiang, J.S. Lian, Surface \& Coating Technology, 201, ( 2007) p. 4594-4600

[57] H. Huo, Y. Li, F. Wang, Corrosion Science 46 ( 2004) p. 1467-1477.

[58] H.Zao, J.Cui, Surface \& Coating Technology, 201, ( 2007) p. 4512- 4517.

[59] J.S.Lian, G.Y. Li, L.Y.Niu, C.D. Gu, Z.H. Jiang, Q. Jiang, Surface \& Coating Technology, 200, (2006) p. 5956- 5962

[60] W. Cheong,B. Luan, D. Shoesmith, Corrosion Science, 49, ( 2007) p. 1777- 1798.

[61] Z. Liu, W. Gao, Applied Surface Science 253 ( 2006) p.2988- 2991.

[62] N. El Mahallawy, H. Palkowski, M. Shoeib and M, Maamoun: Steel Grips, 2(2004)2, p.130 - 139.

[63] N. A. El Mahallawy, H Palkowski, M. Shoeib, M. A. Maamoun, V. Neubert, A.Bakkar, Steel Grips 4(2006) No 3, p. 212-216.

[64] N. A. El Mahallawy, M. Shoeib, A.Bakkar,H Palkowski, A.,and V.Neubert, submitted for publication in Surface \& Coating Technology ( 2007)

[65] Xiang- Y, Hu-W. Liu-X, Zhao- C, Ding- W: Transact. of the Institute of Metal Finishing, 79(2001)1, p. 27-29.

[66] Xiang- Y, Hu-W. Liu-X, Zhao- C, Ding- W: Transact. of the Institute of Metal Finishing, 79 (2001)1, p. 30-32

[67] J. Chem, G. Yu, B. Hu, Z. Liu, L. Ye and Z. Wang, Surface \&Coating Technology, 201 (2006), p. 686-690.

[68] N. A. El Mahallawy, unpublished work, 2007 
[69] M. Matsuoka, S. Imanishi and T. Hayashi, Plating and Surface Finish, 76(1989), p. 5460.

[70] E. Vafaei- Makhsoos, E.L.Thomas and B. A. Shenoi, Metall Trans A, 9 A, (1978), p. 1449- 1454.

[71] M. Matsuoka, S. Imanishi and T. Hayashi, Plating and Surface Finishing, vol.76 (1989)11, p. 54-58.

[72] Y. Wu, Y. Xiang, W. Hu, C. Zhao, and W. Ding, Transactions of the Institute of Metal Finishing, 83( 2005)2, p.91- 94.

[73] A. Vaskelis, A. Jagminien and A.Prokoptcheck, Surface and Coating Technology, 27 (1986), p. 301-310

[74] M. Bayes,R. Ellis and R. House, Metal Finish. 71(1993)2, p.62-64

[75] M.M. Younan and M. Shoeib, Galvanotechnik, 93(2002)4, p. 932-7.

[76] M.M. Younan, I.H.M. Aly and M.T. Nageeb, J. of Applied Electrochemistry, 32(2002), p. $439-446$

[77] H.Zhao, Z. Huang, J.Cui, Microelectronic Engineering 85 ( 2008) p. 253- 258.

[78] W.X. Zhang, Z.H. Jiang, G.Y. Li, Q.Jiang, J.S. Lian, Surface \& Coating Technology, 202, ( 2008) p. 2570- 2576.

[79] Y.W. Song, D.Y. Shan, E.H.Han, Electrochimica Acta, 53 ( 2008) p. 2135 - 2143.

[80] W.X. Zhang, N. Huang, J.G. He, Z.H. Jiang, Q. Jiang, J.S. Lian, Applied Surface Science, 253 ( 2007) p. 5116- 5121.

[81] C. Gu, J.Lian, J.He, Z. Jiang, Q. Jiang, Surface \& Coating Technology, 200, ( 2006) p. 5413-5418.

[82] J.Li, Y. Tian, Z. Huang, X. Zhang, Applied Surface Science, 252, ( 2006), p. 28392846.

[83] W.X. Zhang, Z.H. Jiang, G.Y. Li, Q.Jiang, J.S. Lian, Applied Surface Science, ( 2008) 01.144

[84] M. Anik, E. Korpe, Surface \& Coating Technology, 201, ( 2007) p. 4702- 4710. 